\title{
JUAN CARLOS ONETTI: LA AVENTURA DE LA ESCRITURA
}

But in a fiction, in a dream of passion Hamlet (II.ii.536)

La ficción autorreflexiva convierte en materia narrativa la propia enunciación de textos que cuestionan el proceso creativo en su mismo devenir, procedimiento que la vanguardia histórica convierte en factor predominante de la actividad literaria y la posmodernidad parece haber llevado a límites extremos. Con el agotamiento del realismo mimético la acción narrada se subordina a los códigos de la producción literaria, originándose una narrativa proteica e imprevisible que privilegia la noción de ficción y transforma el acto de contar historias en una aventura de la escritura.

Las rupturas innovadoras que fomentan los movimientos de vanguardia se manifiestan claramente en los primeros relatos de Onetti y en los artículos programáticos que redacta en forma paralela en Marcha. Estos últimos, "La piedra en el charco" y los editoriales que escribe de 1939 a 1941, ponen de relieve el diálogo que entabla la obra artística con el medio cultural en que surge. Son crónicas concebidas como provocación, para romper hábitos mentales conformistas e impulsar un cambio en una época insensible a toda forma de experimentación y de búsqueda expresiva. Con el transcurso del tiempo han adquirido el valor de manifiesto personal - principal estrategia vanguardista- de un escritor que se atribuye la tarea explícita de abrir nuevos caminos, o, como él mismo dice, con ironía, "me adjudico la misión de salvador de nuestras letras”. En esas notas se plantea el estancamiento de la literatura nacional ("vivimos la más pavorosa de las decadencias"), se demanda una 
ruptura total con las modalidades heredadas ("volver la espalda a un pasado artístico irremediablemente inútil”), un abandono del provincialismo telúrico y un distanciamiento de la solemnidad esteticista de "plumíferos sin imaginativa, graves, frondosos, pontificadores con la audacia paralizada". Pretende desacartonar toda pretensión académica (más que a ningún otro admira al escritor "anti-intelectual") e insiste en la necesidad de imponer una literatura urbana, que refleje la situación del habitante de la ciudad moderna. Propone, sobre todo, interiorizar la narrativa ("que el creador de verdad tenga la fuerza de vivir solitario y mire dentro suyo"), renovar sus formas ("expresarse con una técnica nueva, aún desconocida”) y vivificar su lenguaje, que debe ser "espontáneo e inconfundible, [un] instrumento apto para la expresión total", como anota en un editorial de 1939, oportunamente titulado "Una voz que no ha sonado"1. En las mismas fechas, Onetti publica tres obras narrativas donde se define plenamente su visión artística: El pozo (1939), "Un sueño realizado" (1941) y Tierra de nadie (1941).

La multiplicidad de los niveles de enunciación se encuentra ya en sus primeros relatos, cobra importancia primordial a partir de La vida breve (1950), marcada por una progresiva complejidad y ambigüedad, y una formulación autoparódica en sus obras más recientes, en particular en Dejemos hablar al viento (1979), irónica reescritura de un mundo propio. Dos relatos tempranos evidencian la maestría de Onetti para hacer objeto de narración al proceso de narrar — El pozo y "Un sueño realizado". Ambos adquieren una modulación autoconsciente y metanarrativa, donde la presentación de los hechos se entrecruza con una reflexión sobre la creación artística; los dos son textos de convergencia (y distanciamiento) de las propuestas innovadoras de la vanguardia histórica.

No deja de ser revelador que Onetti escribiera —según su propio testimonio - la primera versión de El pozo en 1932, en pleno auge de la prosa vanguardista ${ }^{2}$. Cabe recordar que ese mismo año redacta su primer cuento publicado, "Avenida de MayoDiagonal-Avenida de Mayo" (aparece el 1ํ de enero de 1933), en el que adopta un procedimiento propio de la vanguardia, la simultaneidad de asociaciones mentales y espaciales, la interio-

${ }^{1}$ Juan Carlos Onetti, Réquiem por Faulkner y otros artículos, ed. J. Ruffinelli, Arca-Calicanto, Montevideo, 1975, pp. 56, 30, 19, 30, 19, 31, 44 y 18 , respectivamente.

2 Onetti, "Por culpa de Fantomas", CuH, 1974, núm. 284, p. 223. 
rización de la experiencia. En este relato introduce un principio creativo que singulariza su quehacer literario: la íntima relación dialéctica entre la aventura real y la soñada, el desplazamiento a lo imaginario para expandir la identidad del yo. Un hombre solitario transita por las avenidas de Buenos Aires dejándose llevar por la imaginación, por la ficción de ser otro en un ámbito hostil y alienante. Esta disposición a soñar despierto le confiere al mundo onettiano un carácter onírico cercano a tendencias surrealistas - y señala, por otra parte, el enlace generacional con Felisberto Hernández. Transformar una experiencia concreta en una actividad subjetiva, inventarse identidades posibles (su tercer cuento se titula, justamente, "El posible Baldi", 1936), implantar simulacros o refugiarse en autoengaños, son modos de representar una existencia que tiende a volverse ensoñación, como si vida y literatura fueran mundos intercambiables. El ensoñamiento diurno nace de un inconformismo esencial con lo real objetivo y con todo pensamiento lógico que relegue la imaginación a una función subordinada. Permite, asimismo, ahondar en deseos inconscientes que la razón no puede captar ni apenas vislumbrar.

\section{UNA VOLUNTAD LITERARIA}

La publicación de $E l$ pozo no tuvo ninguna repercusión; sólo recibió un comentario en la prensa montevideana — una sagaz reseña de Francisco Espínola, quien intuye que la novela aporta "un estremecimiento nuevo" a la literatura uruguaya ${ }^{3}$. No es de extrañar que una obra que irrumpe a contracorriente en un ámbito poco propicio al cambio haya pasado totalmente inadvertida. El propio Onetti señala, en la crónica inicial de Marcha, "la ostensible depresión literaria que caracteriza los últimos años de la actividad nacional" y la falta de inquietudes que renueven el curso de las generaciones: "Esto induce a pensar en un país fantástico en que de pronto hubiera desaparecido la juventud y el reloj de la vida siguiera dando siempre la misma hora" 4 . Por su riqueza inventiva y por la creación de una ima-

${ }^{3}$ Francisco Espínola, “El pozo, de J. Carlos Onetti”, El País, 18 septiembre 1940. Recuperada por WiLfRedo PEnco, Correo de los Viernes, 18 noviembre 1983. Recogida y comentada por ANA InÉs LARRE Borges, "Espínola escribe la primera valoración de El pozo", Brecha, 23 octubre 1987, p. 31.

${ }^{4}$ Réquiem por Faulkner, p. 16. 
gen plurivalente de lo real, $\mathrm{El}$ pozo es un punto de referencia ineludible, un texto de fundación de la narrativa hispanoamericana contemporánea. Con él se instaura, definitivamente, una literatura urbana con proyección universal ${ }^{5}$.

$\mathrm{Al}$ reeditarse la novela en 1965 - a 26 años de su publicación-Ángel Rama inicia el proceso de recuperación de un libro que parecía destinado al olvido. Para Rama, el vacío afectivo y físico del narrador "genera la imperiosa necesidad de escribir", una actividad compensadora de su soledad e incomunicación, dramáticamente confesional, que se trasunta en la "posición antiliteraria" que caracteriza la narración ${ }^{6}$. La novela se plantea como una confesión espontánea y directa, pero la distancia crítica que impone un texto enfocado en el acto mismo de narrar pone de relieve no tanto el testimonio existencial como una voluntad literaria.

La urgencia autobiográfica de Eladio Linacero nace de una toma de conciencia de su marginalidad y enajenamiento radical; su relato representa la lucha de quien intenta reconquistar momentos de plenitud subjetiva y de armonía social a través del acto de escritura. Las "memorias" que escribe durante la víspera del día en que cumple 40 años parecen tener la firmeza tranquilizante de la narración realista, la confiabilidad de una experiencia personal. Sin embargo, no se busca la mimesis de un testimonio verificable en la inmediatez cotidiana, que corrobore la autenticidad de lo enunciado. El estrato propiamente narrativo queda subordinado a los años de la imaginación, a las diversas posibilidades de existencia vividas subjetivamente, que trascienden y anulan el ámbito pretendidamente objetivo de la historia contada.

La evocación del pasado permite establecer las conexiones entre las circunstancias rememoradas y las derivaciones imaginarias de un hombre que transforma toda situación en imagen de su deseo. Acechado por el calor, el hastío y la sordidez de la pensión donde vive, sin vínculos humanos (su mujer lo ha dejado, no tiene amigos ni trabajo), Eladio se refugia en la escri-

${ }^{5}$ En Onetti: el ritual de la impostura, Monte Ávila, Caracas, 1981, dedico un extenso capítulo a $\mathrm{El}$ pozo. La presente lectura no es una repetición de ese estudio, sino el resultado de nuevas reflexiones que complementan el trabajo anterior.

6 ÁngEL RAma, "Origen de un novelista y de una generación literaria", en Onetti, El pozo, Arca, Montevideo, 1965, pp. 66 y 69. Todas las citas de la novela se hacen de esta edición. 
tura de sus memorias. Su imaginación tiende a crear formas más armónicas de convivencia, a transmutar soledad, fracasos, odios y obsesiones en proyecciones del ensueño, a inventar un mundo donde existe amor, amistad, comunicación y solidaridad. Cada ficción escritural rectifica una carencia en la vida de un hombre sin otras convicciones más allá del acto de escribir. El ultraje a Ana María en la casita del jardinero en Capurro, ocurrido en su adolescencia, es el "suceso real" que genera "la aventura de la cabaña de troncos" en Alaska; es decir, la actualización temporal de Eladio transfigura el engaño y el sadismo en una imagen de amor inocente y natural, el desprecio de Ana María en entrega amorosa, la violencia en caricia. Todas las demás situaciones de la novela existen como reflejo de un yo escindido que construye aventuras imaginativas con los materiales de su propia desolación, ensueños poblados con las proyecciones de sus deseos insatisfechos.

La sencillez coloquial y la espontaneidad conversacional - engañosamente antiliterarias- distinguen netamente la novela desde su mismo comienzo: "Esto que escribo son mis memorias. Porque un hombre debe escribir la historia de su vida al llegar a los cuarenta años, sobre todo si le sucedieron cosas interesantes. Lo leí no sé dónde” (p. 6). La historia narrada se desenvuelve con naturalidad, pero el fluir rememorante es interrumpido reiteradamente por los comentarios de un narrador consciente de su condición de escritor:

Dejé de escribir para encender la luz y refrescarme los ojos que me ardían. Debe ser el calor. Pero ahora quiero hacer algo distinto. Algo mejor que la historia de las cosas que me sucedieron. Me gustaría escribir la historia de un alma, de ella sola, sin los sucesos en que tuvo que mezclarse, queriendo o no. O los sueños (p. 8).

Eladio anticipa despectivamente una determinada actitud receptiva: "También podría ser un plan el ir contando un «suceso» y un sueño. Todos quedaríamos contentos" (p. 9); e intercala acotaciones que revelan el distanciamiento que hay entre el acto de enunciar y lo enunciado: "Después de la comida los muchachos bajaron al jardín. (Me da gracia ver que escribí bajaron y no bajamos). Ya entonces nada tenía que ver con ninguno" (p. 10). El relato llama la atención sobre los problemas creativos de un narrador que declara no saber escribir: "Otra advertencia: no sé si cabaña o choza son sinónimos; no tengo 
diccionario y mucho menos a quien preguntar. Como quiero evitar un estilo pobre, voy a emplear las dos palabras, alternándolas" (p. 16); la complicidad irónica presupone un lector atento, puesto que repite cabaña diecisiete veces y nunca más usa choza. La carga ilocutoria que tiene la enunciación pone de relieve la disposición metadiscursiva de un texto que se vuelve incesantemente sobre sí mismo:

Si hoy quiero hablar de los sueños, no es que no tenga otra cosa que contar. Es porque se me da la gana, simplemente (p. 8);

Releo lo que acabo de escribir, sin prestar mucha atención, porque tengo miedo de romperlo todo. Hace horas que escribo y estoy contento porque no me canso ni me aburro. No sé si esto es interesante, tampoco me importa (p. 20);

Pero esto tampoco tiene que ver con lo que me interesa decir (p. 37).

Se asiste así al proceso de elaboración de un relato en su propio devenir, acentúandose la reflexión sobre la naturaleza de la escritura. Es decir, se desplaza el interés de las memorias de Eladio al acto de contarlas en un texto que no deja de aludir a su condición de ejercicio literario.

El continuo cuestionamiento de los enunciados y la reiterada anticipación o replanteo de historias, alternando hechos, sueños o ensueños, difieren la crónica circunstancial de Eladio. Su plan expreso es evocar un suceso vivido por él mismo, darle credibilidad a lo escrito; sin embargo, la libre asociación de unidades espacio-temporales desplaza la historia que recompone, defraudando las expectativas del lector $-\mathrm{y}$, naturalmente, reteniendo su atención. La segmentación del texto en dieciocho fragmentos, separados por espacios en blanco, que se yuxtaponen según un montaje de carácter evocativo e imaginativo aparentemente arbitrario, da a los incidentes narrados una relativa autonomía. Eladio cuenta episodios de su vida en el orden en que vienen a su mente, salta de uno a otro según sus vaivenes anímicos, creando un entramado digresivo y discontinuo carente de toda lógica convencional ${ }^{7}$.

${ }^{7}$ JaIme Concha sugiere que hay una "regla general" que regula la novela, el "procedimiento dilatorio de introducir situaciones enteras e igualmente importantes antes de cumplir con lo anunciado" ("Conciencia y subjetividad en El pozo", en Juan Carlos Onetti, ed. H. J. Verani, Taurus, Madrid, 1987, pp. 194-195). 
En $E l$ pozo se pone en práctica la tendencia a la heterogeneidad, a la incongruencia y a la devaluación de los niveles idiomáticos privilegiados que opera desde los años veinte. La única actividad conocida de Eladio es escribir, pero él mismo se considera un escritor fracasado, asumiendo así una postura irreverente frente a la tradición cultural. En el primer segmento de la novela revisa lo que está escribiendo y concluye: "Es cierto que no sé escribir, pero escribo de mí mismo" (p. 7) y hacia el final reitera: "Nada más lejos de mí que la idea de mostrar a Cordes que yo también sabía escribir. Nunca lo supo y nunca me preocupó" (p. 48). Este deliberado desprecio del estilo elevado pone de relieve el carácter insignificante que se le atribuye a la escritura en nuestra época, acentuado al redactar sus memorias a lápiz, en el reverso de las proclamas políticas del obrero Lázaro, entre la mugre y el calor de una pieza de pensión, cuya sordidez se subraya constantemente ${ }^{8}$. Recuérdese como contrapartida el poema de Cordes, una parodia de un estilo preciosista y univalente, que se deleita con su propia suntuosidad. Eladio lo reduce a un

mundo perfecto donde el pescadito rojo disparaba en rápidas curvas por el agua verdosa del estanque, meciendo suavemente las algas y haciéndose como un músculo largo y sonrosado cuando llegaba a tocarlo el rayo de luna... Un rumor de coro distante surgía de las conchas huecas, semihundidas en la arena del fondo (p. 48).

Se trata de un mero alarde ingenioso, "un universo saliendo del fondo negro de un sombrero de copa” (p. 48), es decir, fantasías al margen de un proceso social, que no arraigan en una experiencia vital. La inferencia es clara: se pone en evidencia la frivolidad de concebir lo imaginario como un escamoteo evasivo y narcisista desligado de dimensiones humanas en un contexto cultural concreto.

En "Propósitos de año nuevo" (1939), Onetti reitera su fidelidad a la verdad interior y plantea la necesidad de descartar la afectación cultista tan reverenciada por los hombres de letras de entonces:

8 Jaime Concha establece una convincente relación entre la falta de significación que se le atribuye a la escritura en esta novela y en Memorias del subsuelo de Dostoievski (ibid., p. 175). 
Sólo se trata de buscar hacia adentro y no hacia afuera, humildemente, con inocencia y cinismo, seguros de que la verdad tiene que estar en una literatura sin literatura y, sobre todo, que no puede gustar a los que tienen hoy la misión de repetir elogios, consagraciones y premios ${ }^{9}$.

El rechazo de las modalidades heredadas e institucionalizadas ("una literatura sin literatura") se revela, explícitamente, en su desdén por toda estilización normativa o finalidad retórica que impidan la captación espontánea de una realidad elusiva e imprevisible. Su prosa narrativa se singulariza por elaborar una enunciación alusiva y connotativa que tienda a desestabilizar y corroer la certidumbre cognoscitiva. Se caracteriza, al mismo tiempo, por la búsqueda de un lenguaje que comunique la inmediatez vivencial con absoluta naturalidad, sin ser mediatizada por el artificio artístico — sin "rellenar con literatura", como dirá Morelli en Rayuela ${ }^{10}$. En El pozo cuenta con un lenguaje coloquial que desde entonces adquiere jerarquía literaria, dándole convincente reelaboración estética a un habla corriente y de gran expresividad popular, actitud que lo aproxima a Roberto Arlt, precedente innegable en el ámbito rioplatense ${ }^{11}$. Su prosa enlaza niveles verbales divergentes, desde una dimensión lírica, con un tono evocativo (por ejemplo, en los sueños y en la última secuencia de la novela), hasta situaciones sórdidas, que conservan el vocabulario propio de los bajos fondos, común y lunfardo (en la pensión, en el Forte Makallé y en un bodegón del puerto), de tal modo que el discurso entrecruza diferentes formas idiomáticas que se penetran las unas a las otras, creando así, por convergencia, una lengua viva en constante mutación. Esta mayor conciencia de la pluralidad de escrituras trae como consecuencia incorporar la diversidad de registros verbales en la voz del narrador, romper con la distinción entre lengua literaria y lengua hablada, fenómeno que

${ }^{9}$ Réquiem por Faulkner, p. 44.

${ }^{10}$ Julio Cortázar, Rayuela, Cátedra, Madrid, 1984, p. 646.

11 Sobre la elaboración literaria del lenguaje oral rioplatense, véanse Noemí Ulla, Identidad rioplatense, 1930: La escritura coloquial, Torres Agüero Editor, Buenos Aires, 1990; y EdelweIs SerRA, "El fenómeno coloquial”, Tipología del cuento literario, Cupsa, Madrid, 1978, pp. 153-173. Sobre el vínculo Arlt/Onetti, véase Rose CorRal, "Onetti/Arlt o la exploración de algunos vasos comunicantes", en Reflexiones lingüisticas y literarias, t. 2: Literatura, eds. R. Olea Franco y J. Valender, El Colegio de México, México, 1992, pp. 251-269. 
para Bajtín constituye un aspecto característico de la narrativa a partir de los años veinte ${ }^{12}$.

La obra de Onetti pone de manifiesto la insuficiencia del lenguaje como medio de conocimiento y la incomunicabilidad de las experiencias humanas. En su narrativa el lenguaje deja de ser un instrumento para describir y explicar los destinos de sus personajes y se convierte en un pasaje para una ansiedad vital, revelando su poder alusivo y evocador, su capacidad de irradiar impulsos vitales complejos y pertubadores. Por debajo de la trama narrativa y del registro referencial subyace un trasfondo inquietante que se manifiesta en imágenes, gestos y actitudes, de tal suerte que las palabras se van cargando de una expresividad no comunicable por otras vías. Los hechos que Eladio cuenta encubren estados afectivos irreductibles a toda razón, un comportamiento que trata de reconstruir con alusiones tangenciales, como si toda descripción fuera superflua y toda explicación inútil. Para Onetti, las motivaciones profundas de los actos humanos son siempre inalcanzables:

Se dice que hay varias maneras de mentir; pero la más repugnante de todas es decir la verdad, toda la verdad, ocultando el alma de los hechos. Porque los hechos son siempre vacíos, son recipientes que tomarán la forma del sentimiento que los llene (p. 34).

De allí la intensidad lírica de las evocaciones de Eladio, que encubren tensiones anímicas que deben deducirse más allá del contenido manifiesto de la historia narrada. De hecho, todos sus actos son equívocos, transfiguraciones oníricas de su estado anímico y de sus deseos inconscientes. La novela presenta una serie de secuencias que sugieren el fracaso de las relaciones humanas; con la adolescente Ana María, con su esposa Cecilia, con su amante Hanka, con el obrero Lázaro, con la prostituta Ester y con el poeta Cordes. La suma de cada uno de los episodios reviste de inusitada intensidad emotiva la desolación de un hombre que se sabe un solitario y se contempla en el espejo de su propia impotencia verbal: "Lo que yo siento cuando miro a la mujer desnuda en el camastro no puede decirse, yo no puedo, no conozco las palabras. Esto, lo que siento, es la verdadera aventura" (pp. 20-21).

12 Véase Mijaíl Bajtín, Teoría y estética de la novela, Taurus, Madrid, 1989, pp. 79-81. 
La "verdadera aventura" de Eladio es la de la escritura, la afirmación de los poderes de la ficción. En otras palabras, no hay "verdad" en la experiencia, sólo hay verdad en el relato ${ }^{13}$. Las interpolaciones, rectificaciones y comentarios dirigidos al lector privilegian el continuo trabajo inventivo de un narrador que torna sus memorias en un ejercicio imaginativo y autoconsciente. Se configura así un modo de narrar propuesto como entidad ficticia, como un proceso de exploración de la naturaleza y los límites de la creación literaria.

El paulatino desplazamiento de la confesión espontánea a un segundo plano es el factor dominante en la historia que cuenta Eladio: "Hay miles de cosas y podría llenar libros" (p. 7); "Podría llenar un libro con títulos" (p. 23), repite más adelante, y se refugia en el "torrente de imágenes" (p. 35), en "la aventura de la cabaña de troncos", en la invención de "prólogos" a narraciones posibles, relatos susceptibles de variaciones infinitas: "Pero me quedo con la cabaña porque me obligará a contar un prólogo, algo que sucedió en el mundo de los hechos reales hace unos cuantos años" (p. 9); "Pero la aventura merece, por lo menos, el mismo cuidado que el suceso de aquel fin de año. Tiene siempre un prólogo, casi nunca el mismo" (p. 16). En la narrativa vanguardista el prólogo se inscribe dentro de una estética de lo fragmentario, de una práctica escritural aleatoria e inacabada, hecha de rupturas inesperadas y fecundas. La fragmentación es una estrategia esencial de la modernidad, un modo de expresión elíptico y discontinuo en consonancia con la inestabilidad y disgregación de la imagen del mundo. Como señala Octavio Paz: "la expresión más perfecta y viva del espíritu de nuestra época, tanto en la filosofía como en la literatura y las artes, es el fragmento"14. Esta modalidad de escritura digresiva e inconclusa, que no trama una historia, tiene sus ejemplos más representativos en Fulano de tal (1925) de Felisberto Hernández, volumen donde dos de los cuatro relatos se titulan "Prólogo" y "Prólogo de un libro que nunca pude empezar"; y es llevada a sus últimas consecuencias por Macedonio Fernández en Museo de la novela de la Eterna (inédita hasta 1967), "novela" compuesta exclusivamente de "prólogos" y de "títulos" que se suceden hasta el fin del libro y dedicada al "lector salteado", quien se ve "obligado" a completar la novela por el

13 Véase Bernard Pingaud, La antinovela: sospecha, liquidación o búsqueda, Carlos Pérez Editor, Buenos Aires, 1968, pp. 24-25.

14 Octavio Paz, Corriente alterna, Siglo XXI, México, 1967, p. 174. 
autor. La narrativa se convierte así en un proceso en continuo devenir, que tiende más a la heterogeneidad y a la discontinuidad que a su cierre en una totalidad autosuficiente. Más allá del gesto vanguardista inicial, esta subversión de lo previsible implica un radical cuestionamiento del texto único y definitivo, que será una constante de la ficción contemporánea ${ }^{15}$.

El despliegue de recuerdos, sensaciones, deseos, fantasías y sueños estimula el viaje a través de la conciencia. La urgencia de Eladio por establecer un vínculo humano duradero se agota con la noche en que escribe sus memorias, con la agudización de la temporalidad y del efecto del encierro psíquico y físico en que se va sumiendo. "Ésta es la noche", repite como leitmotiv subjetivo cuando la ensoñación se desvanece con la luz del amanecer, y este sintagma temporal indefinido marca el retorno del autoconocimiento, de la percepción de vivir en la oscuridad perpetua. En el final reconoce el acechante transcurrir temporal ("mi vida no es más que el paso de fracciones de tiempo", p. 52) y queda atrapado por la sordidez del entorno ("solo y entre la mugre"), rodeado de las "bestias sucias" con quienes convive, cegado por un odio turbio ("Tengo asco por todo, ¿me entiende? Por la gente, la vida...”, p. 50) que revela su atormentada inestabilidad e inadaptación social. Su refugio en las ficciones compensatorias es la única salida del pozo, consciente de un enajenamiento que sintetiza en una penetrante imagen de desamparo total: "Ésta es la noche. Yo soy un hombre solitario que fuma en un sitio cualquiera de la ciudad; la noche me rodea, se cumple como un rito, gradualmente, y yo nada tengo que ver con ella" (p. 53). Como arrastrado por fuerzas irresistibles se hunde en las aguas nocturnas que llevan su cuerpo exhausto hacia el anonadamiento:

Las extraordinarias confesiones de Eladio Linacero. Sonrío en paz, abro la boca, hago chocar los dientes y muerdo suavemente la noche. Todo es inútil y hay que tener por lo menos el valor de no usar pretextos. Me hubiera gustado clavar la noche en el papel como a una gran mariposa nocturna. Pero, en cambio, fue ella la que me alzó entre sus aguas como el cuerpo lívido de un muerto y me arrastra, inexorable, entre fríos y vagas espumas, noche abajo (p. 53).

15 Cf. Sylvia Molloy, Las letras de Borges, Sudamericana, Buenos Aires, 1979 , pp. 120-125. 
No es difícil advertir, en definitiva, que una modalidad narrativa frecuente, e incluso sobresaliente en Onetti, se encuentra ya prefigurada en su primer libro publicado: El pozo condensa una forma de narrar válida por su carácter de ficción, que pone el énfasis en el placer de contar, de inventar. Qué duda cabe que esta apertura hacia lo imaginario, la entrega sin reservas a la ensoñación como forma de enriquecer una existencia enajenada, sustenta de modo absorbente la actividad literaria de Onetti a lo largo de sesenta años.

\section{UNA POÉTICA DE LA INTERTEXTUALIDAD}

Si en El pozo sobresale ya el interés de Onetti en la ficción autorreflexiva, en "Un sueño realizado" se introduce otro procedimiento clave de su narrativa: el discurso como intertextualidad, la práctica de la escritura fundada en lecturas previas. Todo texto desarrolla un diálogo secreto o explícito con otros textos que se entrecruzan y se asimilan, se implanta en una tradición cultural que prolonga o subvierte. En este cuento, las irónicas e insistentes alusiones a Hamlet - ocho menciones en los cuatro primeros párrafos y doce en total- desajustan el proceso de lectura: el entrecruzamiento de un discurso aludido o parodiado llama la atención sobre el acto mismo de escribir una ficción. El narrador pretende evocar un acontecimiento del que fue un testigo casual, pero reconstruye una historia en la cual el drama de Shakespeare es el intertexto privilegiado. Las referencias al modelo venerado rescatan su dimensión histórica y establecen un horizonte cultural del cuento, que se fundamenta, por un lado, en la interacción de la apariencia y la verdad; y que plantea, por otro, una actividad narrativa consciente de su carácter teatral, en la cual los personajes actúan al modo de actores que se entregan a un papel que ellos mismos inventan y normalizan. O como dice Hamlet: "The play's the thing" (II.ii.590) — play, en su doble sentido de drama y juego ${ }^{16}$.

La apertura del cuento introduce el intertexto, como "bro-

${ }^{16}$ La crítica ha mencionado ya el motivo hamleteano, sin desarrollarlo: Katalin Kulin, "JCO: «Un sueño realizado»”, Acta Litteraria (Budapest), 19 (1977), 71-76; Harriet S. Turner, "Dinámica reflexiva en dos cuentos de Onetti", $C H(8)$, pp. 645-652; David Lagmanovich, "Acotaciones a «Un sueño realizado", Juan Carlos Onetti, pp. 205-216; Ilán STAvans, "Onetti, el teatro y la muerte", Latin American Theatre Review, 25 (1991), 107-113. 
ma" fundada sobre una mentira (el haberse arruinado Langman, el empresario teatral que narra, por representar a Shakespeare: "La broma la había inventado Blanes... - Porque usted, naturalmente, se arruinó dando el Hamlet"). O también: "-Sí, ya sabemos. Se ha sacrificado siempre por el arte y si no fuera por su enloquecido amor por el Hamlet..."17. Y más adelante: "Y así fue que pude vivir los veinte años sin saber qué era el Hamlet, sin haberlo leído, pero sabiendo, por la intención que veía en la cara y el balanceo de la cabeza de Blanes, que el Hamlet era el arte, el arte puro, el gran arte..." (p. 8) ${ }^{18}$. La lectura de "Un sueño realizado" es guiada implícitamente por las reminiscencias de un drama que responde a mecanismos de ocultamiento y simulacro, a imprevistas invenciones y desdoblamientos que ponen en tela de juicio toda realidad.

Hamlet, un soñador, posterga enfrentarse con la verdad - matar al rey, su tío y padrastro, para vengar la muerte de su padre- y desplaza la venganza hasta el momento de su propia muerte. El destino le asigna un papel que él subordina a una serie de puestas en escena de roles que enmascaran sus actos y se transforman en una condición de la convivencia. En este sentido, Hamlet se inventa a sí mismo; si no está dispuesto a actuar para resolver el problema que lo atormenta, "actúa" al modo de un actor poseído por un papel tras otro. Cada escena le ofrece la oportunidad de representar una serie de situaciones autoconscientes que proyectan un Hamlet que es más una creación de la ficción que una víctima del destino: vengador, loco, príncipe desposeído, hijo obediente, enfermo de amor, revoltoso, poeta, tonto ingenioso, hombre de acción. Llevado por el papel que representa, Hamlet establece una irrealidad dentro de otra que impide saber dónde termina la vida y comienza la ficción ${ }^{19}$.

En "Un sueño realizado", la presencia de una excéntrica mujer de edad indefinida, vestida con la ropa anticuada de "una jovencita de otro siglo" (p. 9), de una extranjera ("la voz, un poco española”, p. 10), pone en marcha el proceso creativo. La llega-

17 Juan Carlos Onetti, "Un sueño realizado", Cuentos completos, CEDAL, Buenos Aires, 1967, p. 7. Todas las citas del cuento se hacen de esta edición.

${ }^{18}$ Langman hace eco aquí de la hipótesis romántica, que suscribe Eugenio María de Hostos en 1873: "Nunca ha producido el arte una creación más pura”, Hamlet, Ediciones Inti, Buenos Aires, 1953, p. 40.

${ }^{19}$ Véase Maurice Charney, Hamlet's fictions, Routledge, New York, 1988. Agradezco además los útiles comentarios de Richard Levin. 
da de un forastero que rompe con la rutina del narrador y viene a llenar un vacío en su vida es un estímulo narrativo constante en Onetti, como ya señalara Josefina Ludmer ${ }^{20}$. La mujer aparece como la sombra de un tiempo inmemorial en el calor sofocante de "la siesta que había durado un montón de años" (p. 13). Es una anomalía en un pueblo de provincia - como la aparición de un fantasma en el castillo de Elsinore- que provoca la imaginación de Langman en la tediosa rutina en que vive. La mujer carece de biografía y hasta de nombre; ningún vínculo la une a los demás. Es, en el sentido de Roland Barthes, una "figura", es decir, una configuración impersonal y anacrónica de relaciones simbólicas ${ }^{21}$. Irrumpe con gestos y movimientos de muchacha, como si entrara en escena "tras una puerta encortinada" (p. 9), afectación teatral que condiciona la iniciación de la escritura. Al verla por primera vez Langman la juzga "una pobre loca" (p. 8), un "bicho raro" (p. 11), y la desconcertante apariencia de la recién llegada lo incita a reconstruir una historia, a descifrar un secreto, un enigma. La frecuente predisposición onettiana a privilegiar la comunicación no verbal (gestos, miradas, muecas, posturas) desencadena una exploración especulativa, una elaboración hipotética que borra el referente. Langman conjetura e infiere lo imprevisible, descubre signos premonitorios que vaticinan —además de la locurauna "muerte repentina" (p. 10). Como autor y director de su propio drama, crea un guión que le permite hacer alarde - como tantos otros narradores onettianos- de su poder para deducir profecías infalibles. Mirar imaginando es un punto de partida usual en Onetti e implica aceptar un desafío a fabular, a construir historias:

No voy a decir que a la primera mirada... yo adiviné lo que había adentro de la mujer ni aquella cosa como una cinta blanduzca y fofa de locura que había ido desenvolviendo, arrancando con suaves tirones, como si fuese una venda pegada a una herida, de sus años pasados, solitarios, para venir a fajarme con ella, como a una momia, a mí y a algunos de los días pasados en aquel sitio aburrido, tan abrumado de gente gorda y mal vestida... Tenía el

20 Josefina Ludmer, Onetti: los procesos de construcción del relato, Sudamericana, Buenos Aires, 1977, p. 20.

${ }^{21}$ Roland Barthes, $S / Z$, Hill and Wang, New York, 1974, p. 68. Citado por Roland S. MÉndez-Clark, Onetti y la (in)fidelidad a las reglas del juego, University Press of America, Lanham, MD, 1993, p. 86. 
pelo casi gris peinado en trenzas enroscadas y su vestido correspondía a una vieja moda; pero no era el que se hubiera puesto una señora en los tiempos en que fue inventado, sino, también esto, el que hubiera usado entonces una adolescente (p. 9).

La sutil tensión entre la apariencia juvenil e inocente que la mujer quiere imponer (los dientes "exhibidos como los de un niño" y los "senos agudos de muchacha", p. 9) y el peso de una tremenda edad que se esfuerza en esconder ("había conservado aquella juventud impura que estaba siempre a punto de deshacerse podrida”, p. 13), es el centro intencionalmente contradictorio sobre el que gira el relato:

La mujer tendría alrededor de cincuenta años y lo que no podía olvidarse de ella, lo que siento ahora cuando la recuerdo caminar hasta mí en el comedor del hotel, era aquel aire de jovencita de otro siglo que hubiera quedado dormida y despertado ahora un poco despeinada, apenas envejecida pero a punto de alcanzar su edad en cualquier momento, de golpe, y quebrarse allí en silencio, desmoronarse roída por el trabajo sigiloso de los días (pp. 9-10).

La mujer contrata a Langman y a Blanes para representar un drama en un teatro vacío, una obra que no está escrita, un sueño que tuvo, que no es más que una escena, sin propósito explícito ni sentido ("allí no pasa nada... no es cuestión de argumentos", p. 12, y sin "ningún significado para ella”, p. 19), pero que se empeña en escenificar para reactualizar un momento de felicidad, porque "mientras dormía y soñaba eso era feliz, pero no es feliz la palabra sino otra clase de cosa" (p. 19). La escena aparentemente inocua e insignficante se reconstruye con gran verosimilitud para que lo soñado se afirme como una vivencia indeleble y real: la mujer se acuesta en la acera, junto a una mesa verde y enfrente de una verdulería con cajones de tomate; hay dos automóviles que cruzan velozmente, una mujer con un jarro de cerveza, un hombre con una tricota azul y una gorra gris, sentado en un banco de cocina, que se inclina para acariciar detenidamente la cabeza de la soñadora. Éste es el sueño hecho ficción teatral que el relato monta como figuración de un deseo indefinido o de un remoto recuerdo que busca su representación. Las imágenes llegadas en sueños crean una zona de silencio, un fondo inasible que alude a un pensamiento informulado del que queda siempre un centro indescifrable. La escenificación de un sueño sin texto, 
sin palabras y sin espectadores es "una transposición en gestos y movimientos de lo que no puede decirse"22. En los sueños, los deseos y los sentimientos no se manifiestan abiertamente sino enmascarados y este proceso de encubrimiento de los impulsos subterráneos es el carácter principal del lenguaje onírico $^{23}$. La representación del sueño de la mujer puede leerse entonces como una concreción de una pasión reprimida, una apertura a zonas de la afectividad en las que no es posible ahondar sin riesgos graves, como la locura y la muerte.

La escenificación teatral incluida en "Un sueño realizado" responde al mismo principio que el drama dentro del drama en Hamlet, la obra que inventa Hamlet y en la que actúa de protagonista para probar la autenticidad de las revelaciones del espectro de su padre. El efecto es similar: la ficción que se construye dentro del marco literario representa, compendiada, la totalidad de la vida de la soñadora y la "realidad" queda subordinada a sus deseos, realizados en la plenitud onírica y teatral. En el sueño la mujer se ve a sí misma "acostada en la acera como si fuera una chica", mientras que el narrador la ve "moviendo el cuerpo como una muchacha" (p. 21). ¿Acaso el sueño la proyecta a otro tiempo para satisfacer deseos preteridos, una afectividad negada a otra mujer, Ophelia? La analogía no es nada frágil24: la timidez, puerilidad y "locura" de la mujer recuerdan el comportamiento de Ophelia. Hay datos que aparecen invertidos: su virginal vestido blanco es ahora negro; su cabello rubio, suelto y sensual es ya gris y está peinado en trenzas enroscadas. Un detalle tangencial es más sugerente y central: el simbolismo floral, que acompaña a Ophelia desde su primera escena hasta su entierro; aparece siempre con una guirnalda de flores en la cabeza y se ahoga coronada de "guirnaldas fantásticas" de flores silvestres. La perversa imaginación de Onetti condena a "la rosa de mayo" (IV.v.155), como la llama su hermano Laertes, a llevar "una rosa en la cintura, tal vez artificial ahora que pienso" (p. 9).

22 JOSEFINA LUdMer, op. cit., p. 89.

${ }^{23}$ Еrich Fromm, El lenguaje olvidado, Hachette, Buenos Aires, 1980, p. 59.

24 Aludo al comentario de Dario Puccini: "Quizá el Hamlet desempeña aquí la función de falso símbolo, ya que, aparte de la frágil analogía con la muerte de Ofelia, no se puede establecer ningún elemento concreto de comparación entre el drama de Shakespeare y la aún trágica performance de la mujer", en "Vida y muerte como representación en «Un sueño realizado» de Onetti", Hispam, 38 (1984), p. 20. 
La imagen de una Ophelia inocente y abandonada "se aparecerá por siglos a los soñadores y a los poetas", dice Gaston Bachelard, y añade: "Como siempre en el reino de la imaginación la inversión de la imagen prueba la importancia de ésta"25. Esta inversión se produce gracias a la proyección del soñador, a su "locura", fingida o real, única manera de lograr el fin deseado (Hamlet, su venganza; la mujer, representar su obra). En el sueño la mujer se escinde en un doble fantasmal, revive deseos de un pasado irrecuperable para perpetuar una comunión más deseable y natural. Al realizarse el sueño, no tiene razón para vivir y muere en el escenario, una muerte desconcertante para el empresario Langman, por "no haber leído" Hamlet. La simple expresión de ternura - la caricia- que la mujer le pide a Blanes se contrapone al tratamiento de Hamlet en la escena de la compañía viajera de actores, cuando se sienta a los pies de Ophelia y la rechaza e insulta, conduciéndola a la locura y al suicidio. La situación dramática de "Un sueño realizado" ha sido apropiada, adaptada y subvertida por la operación intertextual. El desenlace del sueño "transforma la muerte en suicidio", como sugiere Mario Benedetti ${ }^{26}$, y la soñadora refleja e invierte el destino de "una jovencita de otro siglo" que regresa a la imaginación de Onetti a satisfacer un sueño de amor juvenil tan cruelmente frustrado por el destino o por Hamlet. Ophelia necesita una salida para sus emociones: imaginarse una historia y producirla para encontrar la paz antes de morir. Como su única realidad es teatral, para que su sueño se realice debe ser representado en otro drama.

Blanes es una figura hamleteana por excelencia. Se tambalea en el escenario, se enfurece y medita melancólicamente; es autoconsciente, ingenioso e histriónico. Se burla de la superficialidad de Langman, como Hamlet de la de Polonius. Como la mujer, Blanes también vive al margen de la sociedad, enmascarando su vacío interior con la borrachera. Continúa ha-

25 Gaston Bachelard, El agua y los sueños, F.C.E., México, 1978, pp. 130131. Célebres son los cuadros de Delacroix y de Redon; la música de Berlioz, La mort d'Ophélie; el poema "Ophélie" de Rimbaud. El hechizo de Ophelia invade asimismo la cultura popular: Bob Dylan la coloca en "Desolation Row" y muy recientemente merece un blues en el filme Maverick de 1994. Véase Elaine Showalter, "Representing Ophelia", en Hamlet, ed. M. Coyle, St. Martin's Press, New York, 1992, pp. 113-131.

${ }^{26}$ Mario Benedetti, "Prólogo", Un sueño realizado y otros cuentos, Número, Montevideo, 1951, p. 10. 
ciendo el papel de "galán", a pesar de su amenazante decrepitud, "estaba envejeciendo y el cabello rubio lo tenía descolorido y escaso" (p. 18). Estimulado por el remedo de la pasión (se insinúa una relación amorosa con la mujer, como entre Hamlet y Ophelia), se deja llevar por el juego y se sumerge en sus propias ficciones para darle sentido a los años muertos. Las máscaras que se inventa mantienen viva la ilusión de crearse otra identidad: "recorría el escenario, se iba colocando en posiciones de fotógrafo, de espía, de boxeador, de jugador de rugby..." (pp. 17-18). Las pasiones ocultas de la mujer son compartidas por Blanes, como si el sueño y la locura fueran contagiosos, o, como dijera Jaime Concha, a propósito de Tierra de nadie, "como ilusión mutuamente sostenida, como mentira y ficción" 27 . En el final de la representación del sueño, Blanes se compenetra con el rito enigmático e intuye el sentido de su vida, tal como si Hamlet hubiera presenciado Hamlet habría comprendido el sentido de su propia existencia.

Langman aparenta ser un testigo desinteresado que recuerda con indiferencia los hechos que describe. Opta por refugiarse en la simulación como compensación por el desmoronamiento de sus sueños de juventud. "El simulador pretende ser lo que no es", advierte Octavio Paz: "Nuestras mentiras reflejan, simultáneamente, nuestras carencias y nuestros apetitos, lo que no somos y lo que deseamos ser"28. Langman elige una opción acomodaticia, no haber leído Hamlet, cuya constante mención parece no ser premeditada (es sólo una "broma" de otro), pero que contribuye a mutarlo, a extrañarlo y a enajenarlo, quedando enclaustrado en el engaño que resulta de su propia invención y que lo resguarda del fracaso de sus sueños de dramaturgo. Como Polonius, que se ha pasado la vida cerca del teatro, pero era incapaz de comprender sus sentidos profundos, oculta su superficialidad con el silencio. En el presente de la narración, retirado en un "asilo para gente de teatro arruinada" (p. 8) desde donde rememora y escribe, encuentra en la biblioteca un ejemplar del drama que resuelve no leer, para vengarse de "la burla no comprendida del todo de Blanes" (p. 7). Si la mujer se refugia en la "locura", Langman se refugia en un "asilo", consciente de su carácter teatral y vulnerable a la pérdida de

${ }^{27}$ Jaime Concha, "Sobre Tierra de nadie, de Juan Carlos Onetti", Atenea, 44 (1967), p. 186.

28 Octavio Paz, El laberinto de la soledad, F.C.E., México, 1967, p. 36. 
identidad que le impone su profesión. La "broma" de Blanes no es una broma ${ }^{29}$. Langman se ha ido "empapando" del Hamlet "sin dar[se] cuenta" y sin "leer una sola línea" (p. 8), proyección que alimenta su apetito de ser otro, de modificar su vida humillada. El fingimiento premeditado convierte a Langman en una víctima del héroe que desconoce. Su aspecto físico, sus gestos y su lenguaje son los de un actor hábil en representar un papel que se impone como ejemplo de la maestría de Onetti para mantener un diálogo con otro texto más allá de la trama narrativa. De allí la desconcertante dualidad de un yo que se rehace en imagen del fantasma de su propio sueño y termina compenetrado totalmente con la farsa que le ha dado razón para vivir. Refiriéndose a sí mismo comenta que usa "una peluca rubia peinada al medio que prefiero no sacarme para dormir, una dentadura que nunca logró venirme bien del todo y que me hace silbar y hablar con mimo" (p. 8). Llevado por la mascarada sucumbe al hechizo de lo imaginario y se inventa a sí mismo. Con su peluca rubia se convierte en un grotesco remedo de la figura de Hamlet, el rubio danés, a quien cree imitar en la gesticulación de comediante ("hablar con mimo"), ambigua e intencionada sutileza expresiva que establece un lazo paródico (mimus, comediante en latín) de un yo que desdobla su identidad personal. El enmascaramiento mímico constituye un fenómeno esencial de la voluntad de disimulo, un guiño de complicidad con el lector.

El enigma contenido en todo sueño es esencialmente incomunicable. Como en El pozo, nunca se revela de manera explícita el sentido de las ensoñaciones. Se vuelve a insistir en la insuficiencia del lenguaje para elucidar una historia que desafía la comprensión racional: "Pero fue entonces que, sin que yo me diera cuenta de lo que pasaba por completo, empecé a saber cosas y qué era aquello en que estábamos metidos, aunque nunca pude decirlo, tal como se sabe el alma de una persona y no sirven las palabras para explicarlo" (p. 20). Una serie de imágenes (la desolación de la mujer, la caricia, la mirada

${ }^{29}$ Jorge Ruffinelli considera los chistes de Blanes, "bromas tediosas", "una broma de poco fuste... en todo caso muy mecánica", en "Análisis de «Un sueño realizado»", en El realismo mágico en el cuento hispanoamericano, ed. A. Flores, Premià, México, 1985, pp. 169 y 171. También Mark I. MilLINGTON considera que las bromas de Blanes son "chistes menospreciativos tediosamente repetidos", en An analysis of the short stories of Juan Carlos Onetti, Edwin Mellen Press, Lewiston, NY, 1993, p. 19. Traducción mía. 
furiosa de Blanes) producen una repentina revelación que alimenta el deseo de saber de Langman, su inclinación a ahondar en la interioridad, a buscar inciertos sentidos más allá de lo decible. En el cierre del relato reitera, casi con las mismas palabras, la imposibilidad de comunicar la vida secreta, de develar enigmas que nunca llegan a descifrarse: "lo comprendí todo claramente como si fuera una de esas cosas que se aprenden para siempre desde niño y no sirven después las palabras para explicar" (p. 22). La indeterminación y la omisión proyectan una visión de máxima intensidad emotiva y exigen una relación de intimidad con el lector.

Los sueños son experiencias compensadoras de carencias y anhelos desplazados, que permiten, como apunta Ángel Rama, "realizar en el terreno imaginario los deseos que han sido frustrados o todavía no han podido cumplirse en la realidad cotidiana"30. La representación del sueño de la mujer cobra una dimensión "real", que naturalmente sugiere la indeterminación entre los límites de lo real y lo soñado, mecanismo creativo que caracteriza a las narraciones onettianas. El desplazamiento al imaginario tiende a colmar un vacío y la existencia tiende a alcanzar plenitud en las ensoñaciones, pero en éstas siempre -y paradójicamente- se aloja la muerte.

Como Hamlet, "Un sueño realizado" es una obra emparentada con el enmascaramiento y el simulacro. Los tres personajes escamotean una realidad insoportable (la soledad, el envejecimiento y el fracaso de los ideales), eligen el sueño y la mentira para sobrevivir en un mundo corrupto y alienante, entregándose al estímulo de la ficción para que la vida no pierda la pureza del sueño. Es que el sueño es la materialización de la libertad misma y de la perfección, acaso lo más cercano al "arte puro" de que hablara Blanes al comienzo del cuento, al recordar Hamlet: la experiencia onírica es una zona de silencio impenetrable, un suceder atemporal y ahistórico sin motivación consciente que alude a algo esencial e indecible.

Hugo J. Verani University of California, Davis p. 94 .

30 ÁngEl RAMA, "Origen de un novelista y de una generación literaria", 